\title{
The Names of Christ in Fray Luis de Leon's De los Nombres de Cristo
}

\author{
BARRY J. LUBY
}

\section{BOOK I}

B

EFORE ATtempting to unfold the virtues contained in the name of Christ, ${ }^{1}$ Fray Luis insists on first defining the word "name" and explaining its function. After a prayer for divine guidance, he begins.

All things, he says, come from God and in Him all things are contained. It follows that perfection or the approach to it consists in the capacity of a created thing to contain all others. Now, in the case of material things, there are two beings: actual being, which is material, and spiritual being, which is immaterial. The latter we call the name, and it exists in our minds. A name can contain an infinite number of attributes, and, in turn, can also be contained in an infinite number of attributes. We can compare this with a man who is reflected in many mirrors and whose image in turn is reflected back to him.

${ }^{1}$ It is important to remember that De los nombres de Cristo was written by Fray Luis with five ends in mind: 1) to spread and strengthen the Catholic faith;2) to fight heresy; 3) to prove his orthodoxy and innocence; 4) to retaliate against his enemies; and 5) to justify the usage of the Spanish language.

The work is divided into three books in which three fictional characters, Marcelo, Juliano, and Sabino, are going to interpret the different names of Christ in the Bible. Sabino has found a piece of paper on which are inscribed ten names given to Christ. Marcelo claims the authorship and offers to explain why these ten names, among many, most adequately describe the qualities of Christ. He takes the names in sequence - "Pimpollo," "Faces," "Camino," "Pastor," "Monte," and "Padre" and these six names are treated in the First Book. The Second Book commences with a description of the sins and corruption of the times in which Fray Luis warns of the evil that will befall the people if they persist in their blind ways. Marcelo continues with the exposition of the names: "Brazo," "Rey," "Paz," and "Esposo." In the Third Book, Marcelo, Juliano, and Sabino are anxious to know about the other names, such as "Hijo," "Amado," "Jesus," and "Cordero," which are also attributed to Christ. Since the name "Hijo" is especially dear to Juliano, it is he who gives the exposition of this name. 
According to Fray Luis, the name should resemble the thing it represents in character and in sound. While this principle is maintained in the Hebrew language, it is not the case with all languages. Consider the name of God in Hebrew. It is composed solely of vowels which are the spirit of the language. Each vowel can be replaced (and usually is) by another in the same name. Thus, one vowel can represent all others. This characteristic is symbolic of the perfection of God.

Actually there is no name for God that will embrace all His attributes, since they are infinite. For this reason, Christ is known in the Scriptures by many names. Of these, ten embrace more or less his human qualities.

\section{Pimpollo (Bud of a flower)}

Christ is often alluded to as "el Pimpollo" in the Old Testament. Thus, Jeremiah wrote, "Haré que nazca a David, pimpollo de Justicia, y haré justicia y razon sobre la tierra." Isaiah, who also called Christ "el Pimpollo," foretold the establishment of the Church on earth when he said, "En aquel dia será el Pimpollo del Senor en grandeza y gloria." Zachary consoling the people of Israel exclaimed, "Yo haré venir a mi siervo, el Pimpollo" and added, "Veis un varón cuyo nombre es Pimpollo."

The blind of heart, Fray Luis says, have denied that the Messiah is the one referred to in these passages. However, if this is so, it would render their meaning unintelligible. The sages of old prophesied in riddles so that, on the day when their predictions should be realized, the Messiah would be recognized by the signs he brought and the wonders he accomplished.

Closely allied to the name "el Pimpollo" is the name "el Fruto," ("the Fruit"), which is also a symbol of Christ in the Holy Scriptures. This name is appropriate because even as the tree was created not for itself alone but to bear its fruit, so too was the world created not for itself alone but for its Fruit, which is Jesus Christ.

It should be noted that the prophets predicted "el Fruto," springing from uncultivated soil. The reference here is interpreted to mean that the Messiah was to be born of a Virgin who had not known man. David further substantiated this mystery when he said, "En resplandores de sanctidad del vientre, y de la manana contigo el rocío de tu nacimiento." This passage can signify that 
Jesus Christ was to be conceived by the Holy Ghost in the womb of the Virgin Mary. If the meaning of this passage is not evident it is due to the poverty of the Latin Vulgate, which does not adequately translate this particular verse.

\section{Faces (Faces)}

In the Psalms the prophet beseeches thrice, "Conviértenos Senor, $\mathrm{Y}$ ensenanos tus Faces." The repetition is symbolic of the three advents of God: on Mt. Sinai, in the person of Christ, and at the Final Judgment. The blessing that God sent his people was, "Descubre Dios sus Faces sobre ti y haya piedad de tis vuelva Dios sus Faces a ti y de te Paz." In many instances like these where God speaks of showing His countenance to His people, He means the Savior Jesus Christ who was promised to them.

Again in the Canticle, the beauty of Christ's countenance is described in the glowing, physical attributes of the Spouse's countenance. These terms serve to express the many mystical qualities of Christ, such as sincerity and piety, wisdom and understanding, justice and mercy, etc. Since neither tongue nor pen can describe these attributes, their symbols are given in sensuous terms.

Moved by His divine love for men, God sent His only Son so that they might see His countenance as He had promised to the prophets of old. Since God the Son is identical with God the Father, those who saw and recognized God the Son, also saw and recognized God the Father.

\section{Camino (Way)}

Christ is signified when the prophets of old speak of "Camino." Even in the Old Testament Jesus says, "Soy camino, Verdad, y vida." The epithet befits Christ, for He is the Pathway which all men must travel to win salvation. Without Him there is no pathway and no salvation.

The state of the Pathway varies in proportion to the state of the soul. The faint-hearted find it smooth and inviting, but the ardent encounter brambles and obstructions. To travel this Pathway means to suffer injustice and contempt. It means to spurn riches and honors, and many worldly things offered by the paths that are not Christ's. 
Indeed, Christ is the Pathway, because He guides us with His church, He teaches us by word and deed; He enlightens our understanding and, with His love, kindles our will that we may seek salvation.

\section{Pastor (Pastor)}

Christ is called "Pastor" since He gave Himself this name. This name is befitting because the shepherds are the fortunate few who are close to God and nature. In ancient literature the ideal lover was the shepherd who was free from the vice and corruption of men. Left alone, the shepherd plies himself with loving care to his charge. Christ is the Shepherd for He will lay down His life for His flock since His love exceeds that of a hireling.

\section{Monte (Mountain)}

"Y en los postreros días será establedido el monte de la casa del Senor sobre la cumbre de todos los montes." This verse taken from Isaiah is allegorical and definitely alludes to Christ, though to many the sense is obscure. If we take "montes" to mean all the prophets of old, then "Monte" must refer to Christ, since it is He who is above and surpasses all prophets. And to whom are they alluding if not to Christ when they say, "Monte en el cual le plació a Dios morar en el"?

"Monte" is a befitting name for Christ, for like a mount, $\mathrm{He}$ is full of good things which are useful to men. In His abundance man finds the means to satisfy both spiritual and temporal wants.

In Daniel it is related how a small stone destroyed a great idol when it struck it at the base. The stone then grew to enormous proportions covering the earth. Christ is indeed the small stone. With His humility and sufferings He was able to destroy sin, though His beginning was small.

Again in David it is remarked how a handful of seed sown upon the mountain bore good fruit. Christ is that fertile soil upon which our good works thrive. Let us note also that Christ is spoken of as the mountain which is above all mountains: "Y en los postreros días será establecido el monte de la casa del Senor sobre la cumbre de todos los montes." Here, it is clearly meant that Christ is over and above all worldly power and knowledge which from time to 
time have tried to overshadow Him. We saw how Satan with his malice and envy tried to rise above his Master; and we saw, too, how he failed.

\section{Padre (Father)}

Isaiah called Christ "Padre del siglo futuro" because all men must have Him as their Father for the life to come. This divine relationship is achieved by rebirth in the waters of Baptism. For the atonement of sin God sent His only begotten Son on earth to suffer and die. In His sojourn Christ instituted the Sacrament of Baptism. In its waters, man washes away the poison of the serpent and is given new life. Thus Christ becomes our Universal Father and we become united to Him.

\section{BOOK II}

After the introduction, Fray Luis proceeds with the pious narrative of the three friends.

Marcelo, Juliano, and Sabino have paused long enough to eat and rest a while. At noontime they cross over to an islet located in the river Tormes. In the coolness of the dense trees the three religious companions continue to appraise the names of Christ.

\section{Brazo (Arm)}

Christ is called "Brazo de Dios" by the Prophet because through His might Israel was to be delivered from the dominion of her enemies. Many are the expressions which picture the Savior as an armed champion of His people dealing death and destruction to their foes.

Yet it seems strange that God who promised the Jews great power gave it only to their enemies for many centuries. The Assyrians, Babylonians, Medes, Persians, Greeks, and Romans: each nation in turn saw its day of glory and might and yet Israel never once became mightier than any one of these. The answer, says Fray Luis, is to be found in the Scriptures: "Las victorias del cordero manso Cristo no habian de ser derramande sangre ajena." Thus we see that when God promised conquest through His Messiah, He meant the conquest of a lasting home and not of a perishing earth. The promised victories were not to be over people, but 
over sin. How blind were those who expected their Savior to come as a fearful warrior! Many times it would seem that God sends sorrows and suffering to the elect, and to the wicked, prosperity and pleasure. These earthly gains are as chaff in the wind in comparison with the blessings that God has in store for His own.

We see again how the wisdom and might of God works when $\mathrm{He}$ pitted 12 illiterate men, poor and unarmed, against the glory and might of the world. The former were able to establish a spiritual kingdom on earth, while the latter passed away like all things in this world. All these things were accomplished by Christ, "Brazo de Dios" ("Arm of God").

\section{Rey (King)}

Christ is called "Rey" because in the Old Testament on many occasions God promised a King to His people. Now the qualities of a king are a natural aptitude for governing, an interest in the well-being of his subjects, and a way of governing. All these traits Christ the King possesses. We see it in His government of nature, which provides even for the lowliest of his creatures. We see it in the life He lived on earth. No human was alien to Him during His sojourn. Neither did Christ ever seek to escape suffering. How many kings are there today who understand the sufferings of their subjects ? In the kingdom of men, the vassal exists for the well-being of the lords. But in the Kingdom of God all men are lords, and no man is esteemed vile. How different are the earthly rulers from the Divine Ruler whose sole concern is to love and be loved even when His subjects offend Him.

\section{Principe de Paz (Prince of Peace)}

Christ is called "Principe de Paz" - a name which the starry heavens emblazen. It is a mute message of consolation to the weary who have sought peace in the world and have failed. If by peace, as St. Augustine defines it, we mean calm and order, we must look to the stars for inspiration and emulation. We note how each star keeps its place and respects that of its neighbor. They move about under the Providence of God to present a picture of beauty and rest. It soothes the tortured mind by releasing it from the anxieties of life and gives it peace. 


\section{Esposo (Husband)}

Christ is called "Esposo" because of the unity that exists between Christ and His Church; and between Christ and the Soul. This nuptial tie is stronger than any other tie because it is a union of both the flesh and the spirit. Just as in the Trinity, the Holy Ghost is the bond that unites Christ the Spouse with the Church, and the Soul. The bond of the union of the Soul with Christ is achieved through the medium of the Holy Eucharist. The poisoned apple of our first parents was the cause for spiritual and corporeal decay and in the Holy Eucharist is found the antidote against this corruption.

\section{Hijo (Son)}

\section{BOOK III}

It is the morning of the feast of St. Paul. Sabino and Juliano cheerfully greet each other. They discuss the marvelous effect that the pious discourse of the previous day has had on them. They now wonder why the names "Jesus" and "Hijo de Dios" have been omitted. With this in mind they visit Marcelo. Since it is Juliano who brought the omission to light, the two good friends goodnaturedly agree that Juliano should deliver the talk on these names after the siesta.

Juliano begins with the name "Hijo." It is a title that was Christ's before time began. For this reason God has been quoted as having called only Christ, His Son. Christ merits this title because He is one substance and one mind with the Father, and is identical to Him in all respects. Just as all fathers are made known to others by their offspring, so too, God the Father has been made known by God the Son. On earth Christ fulfilled the will and performed the work of His Father and in this manner identified Himself with God.

From what we have seen, the name of "Hijo" applies to Christ because $\mathrm{He}$ was engendered by the Father; He was born of the Virgin Mary; He was reborn again when He arose from the dead; He relives in the Host; and He is born anew when He makes our souls His abode.

When Christ is born again in the soul we call this the infant. In this stage the soul is governed and directed by Christ. At times it grows rebellious since it is still subject to vain pleasures and de- 
sires. In the adolescent stage, Christ is fully entrenched in the soul; new graces are fused within; and the vain pleasure and desires are rooted out. In the final or mature stage, Christ becomes its undisputed Master. The soul and Christ become one in will. It follows the sweet impulses of wisdom and delights in the knowledge of God.

Just as Juliano finishes his discourse, three black birds are seen attacking one little song bird. It tries valiantly to defend itself but is forced down and consequently is swallowed up by the river below. The malefactors depart triumphantly, much to the sorrow of the three religious men. Their sorrow is changed to joy when the little bird they believed drowned appears again.

\section{Amado (Loved One)}

Christ is called "Amado," especially in the Canticles, in St. Matthew, and in St. Paul. This title is befitting, for He loves and is loved by all creatures. To be loved is the nature of Christ and for this end $\mathrm{He}$ was engendered by the Father.

\section{Cordero (Lamb)}

Christ is called "Cordero" since He is meek, pure, and guileless. These qualities were readily recognizable in Him when He walked the earth. Now that He is in Heaven, He continues to tolerate countless injuries with the mildness of a lamb.

\section{Jesus}

Jesus is one of the names given to Christ, and sums up all the attributes of the Savior. While the name "Jesus" is in keeping with the attributes of His human nature, the other name, "el Verbo" ("the Word") is in keeping with His spiritual nature.

In Hebrew the name of the Second Person as revealed by God, was "Dabar," which is the equivalent of the Greek "Logos" or Spanish "El Verbo." When each letter is considered apart from the other, they mean in Hebrew: "Guide"; "Builder of Eternity"; "The Beginning." All these names are truly attributes of God. The two syllables "Da" and "Bar" mean "the Son," which again is a quality of the Second Person. "Bar" reads in reverse "Rab," which can be translated as "master" or "wise one." 
The name "Jesus" or "Joshuah" applies to the human nature of Christ and contains all the letters necessary to spell the name of God in Hebrew. In this language the name of God, though written, is unspoken. The name of Jesus from which it is taken, is spoken. This is a sign that as a man Christ was made visible to the senses.

Jesus means "health" or "salvation," a name befitting to express the great need which our sickly souls have. It is also befitting because it is the epitome of all the other names such as "Pimpollo," "Monte," "Camino," "Esposo," "Pastor," etc. In each of these names lies the key to salvation. While external practices like fasting, flagellation, and poverty are laudable, only Christ Jesus, Fray Luis says, can give spiritual health.

Fairleigh Dickinson University

Rutherford, New Jersey 